\title{
Review
}

\section{The ethics of immigration}

\author{
Joseph H. Carens \\ Oxford University Press, Oxford, 2013, xvii+364pp., ISBN: 978-0190246792
}

Contemporary Political Theory (2017) 16, 151-154. doi:10.1057/cpt.2015.61;

advance online publication 24 November 2015

This is an important book. In its pages, Carens defines the political theory of migration: a field that, to a large extent, he also founded. Since his article advocating Open Borders appeared in the late 1980s (Carens, 1987), migration went from being the afterthought of a discipline that had no time to waste on the boundaries of the nation-state, to being one of its central concerns. Throughout this process, Carens' articles have always been key references. This book encompasses and supersedes those articles; it responds to the challenges made by Carens's many critics; and it defines the terms of the conversations that have taken shape over these years. The Ethics of Immigration, then, is the required companion to the field.

The book's central questions are whether and why morality requires rich democratic states to make important policy changes in the realm of immigration. To deal with this question, Carens divides the book into two parts: the first treats the problems that arise when migrants are already in a receiving country (Who belongs?); the second puts the question of whether countries should admit new immigrants (Who should get in?). Broadly speaking, Carens argues that certain democratic principles, ones that are widely accepted in receiving countries, imply that current immigrants should be given more legal rights that they are currently granted, and that receiving countries should admit many more people, especially refugees. Democratic states know better, and they should do better.

Carens argues from a 'theory of social membership'. The theory's main claim is that 'living in a society over time makes one a member, and being a member generates claims to legal rights and to legal status' (pp. 159-160). For Carens, fully belonging to society is a fundamental human interest. Members of societies have moral claims to legal citizenship because fully belonging is necessary to develop relationships and live complete human lives. Moreover, democratic countries already recognize that belonging to society is a fundamental human interest, since in them there is a widespread acceptance of the citizenship rule of ius sanguinis, which gives children their parents' citizenship at birth. Children need to belong to the society where they are expected to live as they grow up, and making them proto-citizens through ius sanguinis allows them to create the bonds required for their development

(C) 2016 Macmillan Publishers Ltd. 1470-8914 Contemporary Political Theory Vol. 16, 1, 151-154 
as persons. In Carens' view, democratic countries commitment to ius sanguinis is an acknowledgment of this fundamental human interest in full belonging. Hence, he argues, countries should also grant birthright citizenship to all children expected to grow up in the country, including the children of immigrants. So, besides ius sanguinis, democratic societies should also implement ius soli. But the same principle applies to children who were born elsewhere and are growing up in the democratic society in question, hence, by extension, the principle also applies to adults who have made the society their home. When we ask the question of whom should a society naturalize, and what a society owes to newcomers, we should also think in terms of social membership. Temporary workers, permanent residents and irregular migrants can claim legal rights if they have been living in a society long enough. An immigrant, when she is embedded in dense network of social relations, has become a part of society. She then, according to Carens's theory, clearly has fundamental interests in staying, and a receiving country should recognize this as part of her 'membership-specific human rights' (pp. 100, 161).

Using the theory of social membership, Carens answers many politically charged questions regarding the naturalization and inclusion of current immigrants. For example, he argues that the legal differences between citizens and legal residents are minimal. He holds that democratic countries should ease the requirements for naturalization, because they should not raise the bar much higher for foreigners than they do for current citizens (who get rights to vote automatically at the age of majority). For the same reason, countries should make formal rules and foster informal norms to prevent discrimination, and include members of society who have different languages, customs or religious traditions. Diversity of views and cultural habits should be very loosely contained by a liberal democratic civic culture that must accept cultural and ethnic difference both legally and socially.

The Ethics of Immigration makes several controversial proposals, the most controversial perhaps concerning the rights of temporary workers and irregular migrants. Regarding the first, Carens holds that, beyond their temporary character, democratic justice does not permit many distinctions between the rights of temporary migrants and the rights of citizens. Temporary workers should therefore enjoy a comparable set of rights than resident aliens enjoy. Regarding irregular migrants, Carens argues that those people who have lived long enough to become members of society are entitled to the same rights as other members. But irregular migrants who have arrived recently are also entitled to an extensive set of rights. The reason is that democratic states are legally obliged to provide human rights to everyone in their jurisdiction: these include a right to security, right to a fair trial, freedom of religion and freedom of speech. Besides human rights, regular migrants should also have work-related rights, such as the right to be paid for their work and have legal recourse to get back past wages; even though they may not have a right to legally work in the country. However, these rights are often not available to irregular migrants because gaining access to them puts the migrants in the way of authorities that have 
an interest in deporting them. Yet, Carens argues, irregular migrants should be able to access the rights to which they are entitled, and the state should insure that they have such access. This is the rationale in his 'firewall' argument, the conclusion of which is: 'Democratic states should build a firewall between the enforcement of immigration law, on the one hand, and the protection of general human rights, on the other' (p. 133).

Carens realizes that there seems to be a contradiction in all this. He claims that states must grant and protect the rights of irregular migrants, yet he also claims that states must simultaneously seek to curtail irregular immigration and fight irregular entry and illegal work. His response is that states should insure a migrant's right not solely because this is a moral right of immigrants, but primarily, because states have a moral obligation to sustain a democratic society under their jurisdiction, a society that upholds human rights. Fighting irregular entry is a secondary moral consideration. Consistent with his view of what values a democratic society should prioritize, Carens moves to argue for why states owe duties to would-be immigrants outside their borders.

In the second part of the book, Carens asks who should be allowed into a country. Observing our current economic and political circumstances, he examines which criteria of exclusion are acceptable for rich democratic countries and asks who should a country allow in, he also asks what obligations the rich democracies owe to refugees. The short answer to both questions is that rich democratic countries are morally required to take many more people than they currently do. This requirement is patent when the democratic countries helped to create the conditions migrants are fleeing from, but it also obtains in circumstances where the democracies are not at fault. As members of the state system that requires every person to be a legal member of a state, each state shares in responsibility to ensure that there are no stateless people. They are also responsible for ensuring that other states in the neighborhood of a crisis are not overburdened with refugees. Finally, they owe duties to migrants as fellow persons: migration is a humanitarian concern. Even though Carens concedes that there are limits to how many refugees a country could take, he makes clear that currently countries use this excuse too soon. Rich democracies, in particular, should be expected to make sacrifices when they fulfill their duties to others.

In the last part of the book, Carens makes a case for Open Borders. To do this he uses the 'method of shifting presuppositions'. Using this method means that we do not start making an argument about justice in immigration, either by arguing what justice is from scratch, or by adopting other theorists' view of justice or democratic theory and building up from there. Rather, he adopts a 'continuum of possible presuppositions that stretches from the way things are now to the way they ought to be' (p. 300). In each of these possible settings, he looks for the ideals that structure political life for a given society, and brings those ideals to bear on the problem at hand. Carens begins from a world in which is common practice to turn away at sea boats full of desperate asylum seekers, and works with the norms and the 
expectations of current citizens in that world. But as he goes along, Carens shows that many of these expectations are morally unsound. He then shifts the presuppositions and moves to a just world of fairly equal countries, where there are no refugees or asylum seekers, immigration is uncommon, and borders can be wide open. His case for Open Borders clarifies the author's underlying plea to make democratic principles of freedom and equality consistent across borders, and to include all foreigners among those who are treated as equals.

Many think of Carens's underlying idealism as his weakest point. Yet, it strikes me as the necessary conclusion of any consistent application of liberal democratic theory. In the consistent liberal's view closed borders are concessions to the need to deal with current problems, but universalism should be the default position. The criticism of a consistent liberal would be that Carens does not go far enough. My concerns point in a different direction: Carens assumes that the 'real world' problems are problems of application (if only we were more consistent applying our liberal democratic principles ...). Yet, Carens does not stop to ask if there could be a problem within liberal democracies' principles themselves. The Ethics of Immigration does not explicitly consider a theoretical tension that dogs its argument: liberal democracy requires borders because liberal polities need territorial extent and limited homogenous legal jurisdictions. Yet, liberal theory provides no justification for territorial borders or jurisdictional boundaries. In traditional liberal democratic theory - think of Rawls' or its cosmopolitan versions - borders are either a starting assumption, or a non-ideal concession to historical events. For this sort of liberal democracy, there are no ideal borders. This sort of liberal democracy cannot account for why citizens' privileges or legal jurisdictions stop at a territorial boundary. Hence, Carens's proposal for open borders is itself a temporary fix for a theoretical framework that cannot justify borders in general and yet requires them. Could it be that immigration crises are a symptom of a problem in those principles that legitimize the liberal democratic state, rather than a problem of application of those principles? One of the many merits of Carens's work is its taking liberal states to task for failures in applying principles. Another merit is showing that political theory still has much to do in this area.

\section{Reference}

Carens, J. (1987) Aliens and citizens: The case for open borders. Review of Politics 49(2): 251-273.

Paulina Ochoa Espejo

Haverford College, Haverford, PA 19041, USA pochoaespe@haverford.edu 